\title{
The status of Argentine parrots
}

\author{
M. NORES and D. YZURIETA
}

\begin{abstract}
Summary
Twenty-eight species of parrot have been recorded in Argentina. Most of them inhabit forests in the northern part of the country. The conservation status of Argentine parrots is serious, especially as regards the large species. Of the 11 species of macaws and amazons that formerly existed there, only four now occur for certain. Today, it is still possible to find flocks of many of the remaining species, but several of them have declined. The main problems affecting these species are habitat destruction, primarily of the Misiones forest, and international trade. The large number of species without authorized export quotas for 1993 indicates a very good level of protection for these species, but the authorized quotas for the remaining species are generally high.
\end{abstract}

Veintiocho especies de loros han sido registradas en Argentina, la mayoría de las cuales habitan selvas en el norte del país. El status de conservación de los loros argentinos es serio, especialmente el de las grandes especies. De las 11 especies de guacamayos y amazonas que existieron antiguamente, sólo cuatro ocurren con seguridad en la actualidad. Aunque todavía es posible encontrar bandadas de muchas de las especies restantes, muchas de ellas han declinado. Los principales problemas que afectan a estas especies son la destrucción del habitat, principalmente las selvas de Misiones, y el comercio internacional. El gran número de especies sin cuotas de exportación autorizadas para 1993 indica un muy buen nivel de protección para estas especies, pero las cuotas autorizadas para el resto de las especies son en general altas.

\section{Introduction}

Olrog (1959, 1979) and Forshaw (1978) reported 27 species of parrot from Argentina, and recently a 28th, the Purple-bellied Parrot Triclaria malachitacea, has been recorded in Parque Nacional Iguazú (Rumboll 1990) and on Arroyo Urugua-i (Canevari et al. 1991).

Two-thirds of these species inhabit forest in the northern part of the country, mainly in the Paranense forest of Misiones, montane forest of northern Salta and Jujuy, and gallery forest along the Río Paraguay and its tributaries. The remaining one-third occur in several distinctly different habitats, ranging from sea-level to the Andean zone and from the Bolivian and Paraguayan border to Tierra del Fuego.

In general, the conservation status of Argentina's parrots is serious, especially as regards the large species. Of the six species of macaw that formerly existed there, only the Yellow-collared Macaw Ara auricollis still occurs for certain. Of the five amazon species recorded, four are rare, uncommon or have disappeared 
from the country. One of them, the Vinaceous Amazon Amazona vinacea, was very common in former times (White 1882), and another, the Alder Amazon $A$. tucumana, was, apparently common. Today, it is still possible to find flocks of many of the remaining species, but several of them have declined.

The main problems affecting these species are habitat destruction, primarily involving the Misiones forest, and international trade. After 1984, when Bolivia markedly reduced its export of parrots, Argentina became the principal parrot exporter in Latin America, and by 1985 it was the source of $53 \%$ of all the specimens imported into the United States (Jorgenson and Thomsen 1987). However, it must be emphasized that many of these exported parrots were not originally from Argentina, but rather came from neighbouring countries where their trade was banned or restricted. This "laundering" was apparent because some of the species exported from Argentina are not found in the country: Olive-throated Conure Aratinga nana, Jandaya Conure A. jandaya, Greenrumped Parrotlet Forpus passerinus, Black-billed Amazon Amazona agilis and Black-winged Lory Eos cyanogenia. Furthermore, traders exported large numbers of birds that are rare in Argentina, such as Peach-fronted Conure Aratinga aurea and Canary-winged Parakeet Brotogeris versicolurus, or only moderately common, such as Nanday Conure Nandayus nenday, of which 45,229, 46,522 and 114,560 specimens respectively were exported between 1985 and 1990. It seems likely that many of these birds were of another country of origin.

The data presented here on parrots exported from Argentina between 1985 and 1990 were taken from Edwards and Villalba Macías (1992). The export quotas for 1993 were taken from Anon. (1993). Exports in 1990 reflect a fall in the number of birds exported and the number of species exported. The large number of species without authorized export quotas for 1993 indicates a very good level of protection for these species, but the authorized quotas for the remaining species are generally high.

Numbers in parentheses following the localities and date indicate the approximate number of birds observed. The records are listed from higher to lower numbers of birds observed. All records without attribution to an observer are our own. The date indicates the day we began counts at each site.

Abbreviations used are: MACN, Museo Argentino de Ciencias Naturales "Bernardino Rivadavia" (Buenos Aires); IML, Instituto Miguel Lillo (Tucumán); LACM, Los Angeles County Museum (Los Angeles, USA).

\section{Species accounts}

\section{Glaucous Macaw Anodorhynchus glaucus}

The Glaucous Macaw is virtually extinct in Argentina, although it was common along the ríos Paraná and Uruguay until the late eighteenth century (Sánchez-Labrador 1767, Azara 1805, d'Orbigny 1835-1847). It has not been recorded in the wild in the twentieth century. The species may have had a distribution over the provinces of Misiones, Corrientes and the eastern part of Formosa and of Chaco, and probably Entre Ríos and Santa Fe (see Collar et al. 1992 for a compilation of data, and Chebez 1994). 
Yamashita and Valle (1993) consider that this species was a palm-nut specialist, and that the chatay Butia yatay is the only species of colonial palm with suitable nut in its former range. They also argue that the virtual extinction of the Glaucous Macaw was related to the decline of this palm through the longterm effect of the introduction of domestic herbivores. The only problem with this hypothesis is that the chatay does not occur in some areas, such as eastern parts of Formosa and Chaco, where the Glaucous Macaw was recorded.

\section{Caninde Macaw Ara caninde (= glaucogularis)}

The Caninde Macaw is virtually extinct in Argentina or it occurs only occasionally. Because of the few references available, it seems that it was never common in Argentina, but was probably of regular occurrence (Holmberg 1898, Lynch Arribálzaga 1920). The only relatively recent data were provided by Hoy (1969), who in 1952 observed six birds in northern Salta over the Río Carapari. Although he assigned them to Ara ararauna, most probably they were $A$. caninde (Ridgely 1981).

Olrog (1979) mentioned that the Caninde Macaw was rediscovered in Yacuiba, Bolivia, on the Argentine border. However, Ingels et al. (1981), who studied a blurry photograph of the Yacuiba bird, placed this record in doubt. The species was recently rediscovered in the department of Beni in Amazonian Bolivia by Jordan and Munn (1993), but its occurrence in Argentina is improbable.

The Caninde Macaw has been reported from the provinces of Salta, Formosa, Chaco and Misiones. Canevari et al. (1991) consider that the records from the three last provinces refer to the Blue-and-yellow Macaw A. ararauna.

\section{Green-winged Macaw Ara chloroptera}

The Green-winged Macaw is virtually extinct in Argentina or it occurs only occasionally. There is no evidence that it might have been common in the past, but it did occur regularly, at least until the late eighteenth century (Fontana 1881, Holmberg 1898, Lynch Arribálzaga 1920). The only specimen collected (deposited at MACN) dates from 1917 and is from the province of Formosa, this being the last concrete record in the country. Recently, four birds appeared in the Parque Nacional Iguazú, but it is possible that they were escapes, because they were very quiet (C. Saibene verbally 1993). However, because Ridgely (1981) noted that as the species still occurs in adjacent south-eastern Paraguay, occasional occurrence in Argentina remains possible.

The Green-winged Macaw has been recorded in the provinces of Salta, Formosa, Chaco and Misiones.

\section{Military Macaw Ara militaris}

The Military Macaw is now very rare in Argentina. The last specimens collected date from 1930 and are from Salta (Playa Grande) and Jujuy, and are deposited at MACN. The only relatively recent records are by C. C. Olrog (verbally 1984), who had observed this species two or three years previously, over the Río Itaú 
in northern Salta, and R. Clark, who saw two birds in Parque Nacional Baritú on 2 September 1991 (Chebez 1994). On 25 September 1987, we observed two birds in Tarija department, Bolivia, $40 \mathrm{~km}$ from the Argentine border. Its continued occurrence in Argentina is thus probable.

The species was apparently regular in northern Salta and in Jujuy.

\section{Yellow-collared Macaw Ara auricollis}

The Yellow-collared Macaw is the only macaw known with certainty to persist in Argentina. The species is fairly common in northern Salta and in Jujuy and uncommon in southern Salta. Our records are:

Angosto del Pescado, Salta, 30 July 1989 (40-50: L. Salvador verbally);

Campo Largo (Río Itaú), Salta, 30 September 1982 (20-25);

20 km NW Agua Blanca (over the Río Bermejo), Salta, 22 October 1982 (20);

Los Cedros, Jujuy, January 1975 (15);

Agua Blanca, Salta, 21 October 1982 (10);

Acambuco, Salta, 1 October 1982 (8-10);

Cedro Solo, Río Santa María, Salta, 14 June 1987 (4-6);

Senda Hachada, Salta, 24 June 1987 (4-6);

Parque Nacional El Rey Salta (J. Beltrán verbally).

The species recently colonized the Parque Nacional Calilegua, Jujuy (Canevari et al. 1991, L. Salvador verbally), indicating that it is expanding its range.

Apart from Salta and Jujuy the species has been listed for Formosa (Zotta 1937) and Misiones (Peters 1937), but these records are probably erroneous.

Between 1985 and 1989,758 specimens were exported, but none was in 1990. Moreover, no export quota was authorized for 1993.

\section{Blue-winged Macaw Ara maracana}

The Blue-winged Macaw is most probably extinct in Argentina although it was formerly common (W. Partridge fide Chebez 1990). Chebez (1990) considered that a flock of parrots he photographed in February 1980 in the lower Arroyo Urugua-i belonged to this species. If this were so, it would be the only relatively recent record.

Until 1959 the species occurred on the Arroyo Urugua-i (Navas and Bó 1988, LACM: 2 specimens), Tobuna (Navas and Bó 1988, LACM: 13 specimens) and Parque Nacional Iguazú (Eckelberry 1965). In IML there is one specimen which was collected in 1947 (Arroyo Tigre) and another in 1956 (Montecarlo).

Formerly, the species inhabited most of the province of Misiones and also northern Corrientes, where a specimen was captured in Manantiales and deposited in the Museo Amado Bonpland, Corrientes (J. Contreras in litt. 1081).

\section{Blue-crowned Conure Aratinga acuticaudata}

The Blue-crowned Conure is common to fairly common in most of its range, occurring from Jujuy, Salta, Formosa and Misiones to San Juan, San Luis, La Pampa and south-western Buenos Aires. 
The sites at which we have recorded significant numbers of birds are:

Quebrada de Sébila, La Rioja-Catamarca border, 15 January 1983 (150-200);

Reserva de Copo, Santiago del Estero, 23 July 1983 (150-200);

Sachayoj, Santiago del Estero, 23 September 1990 (150-200: S. Salvador verbally);

Villa de Soto, Córdoba, 22 August 1975 (80-100);

Bañado de Figueroa, Santiago del Estero, 15 July 1980 (60-80);

Los Pocitos, Córdoba, 5 January 1981 (60-80);

Dique Sumampa, Catamarca, 23 July 1982 (60-80);

Pozo del Tigre, Formosa, 1 June 1989 (6o-8o);

Villa Angela, Chaco, 15 December 1982 (50-60: S. Salvador verbally);

Villa Ana, Santa Fe, 28 March 1975 (40-50);

Vilismán, Catamarca, 22 March 1983 (35-40);

Cerro Colorado, Córdoba, 26 July 1974 (30-40);

Ingeniero Malmén, Córdoba, 22 August 1974 (30-40);

El Cantadero, La Rioja, 6 December 1981 (20-25);

Riacho Pilagá, Formosa, 2 October 1987 (15-20).

Although the numbers recorded in the wild are not very large, between 1985 and 1990 no fewer than 94,144 parrots belonging to this species were exported. This high level of exploitation is probably a serious threat to the species. The export quota for 1993 was 8,000, which is itself a high number.

\section{Mitred Conure Aratinga mitrata}

The Mitred Conure is generally fairly common. Locally it is common and even abundant.

The sites at which we have recorded the largest numbers are:

Sierra de Balcosna, Catamarca, 21 January 1983 (500);

Sierra de Balcosna, Catamarca, 11 January 1987 (500);

Serranía de Calilegua, 11 October 1984 (300-400);

Campo Largo, Salta, 30 September 1982 (200);

Campo de Pucará, Catamarca, 20 January 1983 (100);

Sierra Colorada, Salta, January 1989 (100);

Arroyo El Durazno (Dique Sumampa), Catamarca, 30 December 1991 (30).

The Mitred Conure inhabits the north-western mountain of Salta, Jujuy, Tucumán, and adjacent areas of Catamarca. The records from Córdoba (Frenzel 1891, Salvadori 1891) and La Rioja (Giacomelli 1907) are doubtful.

The species did not appear in international trade until 1984 (Nilsson 1985) but, from 1985 to $1990,108,033$ birds were exported. This undoubtedly constituted a serious threat to the species, but in 1993 no export quota was authorized.

\section{White-eyed Conure Aratinga leucophthalmus}

The White-eyed Conure is common in Salta, Jujuy, northern Tucumán and Misiones, and fairly common in the eastern parts of Formosa and of Chaco, and northern Corrientes. There is a recent record in Entre Ríos (Torrano 1990) but not from the rest of its reported range (Catamarca and Santa Fe). The records 
from Santiago del Estero (Zotta 1937), Córdoba (Olrog 1979) and San Luis (Casares 1944) are probably erroneous. The current populations in north-eastern Buenos Aires - Punta Lara (Klimaitis and Moschione 1987) and Parque Lezama, Buenos Aires City (pers. obs.) - possibly originated from escapes.

The sites at which we have recorded the largest numbers are:

Campo Largo, Salta, 30 October 1982 (200-300);

Aguas Chiquitas, Tucumán, 30 October 1979 (150-200);

Pepirí Miní, Misiones, 25 July 1982 (80-100);

Río Jordán, Serranía de Calilegua, Jujuy, 7 October 1984 (50-60);

Arroyo Garuhape, Misiones, 16 June 1984 (40-50);

Campo Viera, Misiones, 6 December 1984 (40-50).

The number of parrots exported in the period 1985-1990 was 31,169, indicating trade as a serious threat to the species, but no export quota was authorized for 1993 .

\section{Peach-fronted Conure Aratinga aurea}

The Peach-fronted Conure is rare in Argentina. The only recent records are:

Riacho San Hilario, Formosa, 4 October 1987 (2);

Las Lomas, Corrientes, May 1983 (1: J. Contreras verbally).

The previous records date from June 1956 when nine specimens were collected on two consecutive days in Monteagudo (4) and in Riacho Negro (5) in the province of Formosa (Olrog 1958). There are also records from Salta, Chaco and Misiones.

From the notes of Holmberg (1898) we infer that this species was common at the end of the last century. From the nine specimens captured in 1956, we also deduce that it was then common in eastern Formosa. Azara (1805) reported that it was not very scarce in Paraguay and down to $28^{\circ} \mathrm{S}$ (i.e. north-eastern Argentina), and that it was sometimes to be found in dense colonies.

The reason for its apparent decline in Argentina does not seem to be habitat destruction, since in eastern Formosa and Chaco its preferred habitat - gallery forest - is well preserved.

Despite its low numbers, between 1985 and 1989 as many as 45,154 birds were exported. Clearly these birds were not from Argentina but from Brazil, where the species is more numerous and its trade is banned.

Birds exported in 1990 totalled only 75 and no export quota for 1993 was established.

\section{Nanday Conure Nandayus nenday}

The Nanday Conure is fairly common in the eastern part of Formosa and the Chaco, and uncommon or occasional in the rest of its range (Misiones, Corrientes and northern Santa $\mathrm{Fe}$ ). The record from Santiago del Estero (Canevari et al. 1991) is probably erroneous. The population now existing in north-eastern Buenos Aires (Klimaitis and Moschione 1987) most likely originated from escapes.

The sites at which we have recorded the largest numbers are: 
Riacho He He, Formosa, November 1986 (80-10o);

Riacho Pilagá, Formosa, October 1987 (60-80).

In the rest of its range the numbers recorded do not exceed 10-15 individuals (see also Contreras 1993).

Although the wild populations of Nanday Conure are not large in Argentina, 114,560 parrots were exported between 1985 and 1990. This clearly indicates that these birds are not only from Argentina but mainly from Brazil and Paraguay, where trade is banned. This undoubtedly constitutes a serious threat to the species. The quota for 1993 was 6,400 birds, which is a high number.

\section{Burrowing Parrot Cyanoliseus patagonus}

The Burrowing Parrot is distributed from southern Salta to Santa Cruz, but its status varies in different zones of Argentina. In some of them, it is still common or abundant; in others fairly common, and in others, such as Córdoba (Nores et al. 1983) and eastern Buenos Aires (Bucher and Rinaldi 1986, Moschione 1992), it is rare or occasional.

The important sites where we have recorded this species are:

Concarán, San Luis, April 1980 (1,000);

Winifreda, La Pampa, February 1982 (500);

Salar de Pipanaco, Catamarca, 2 November 1985 (500);

$30 \mathrm{~km}$ tract between the Desembocadura del Río Negro and La Lobería, Río Negro, 12 January 1986 (500);

$100 \mathrm{~km}$ tract between La Toma and Santa Rosa (NR 148), San Luis, August 1979 (200-300);

San Pablo Norte, San Luis, 22 January 1981 (150-200);

Picún Leufú, Neuquén, 6 February 1982 (150-200);

$400 \mathrm{~km}$ tract in south-western Buenos Aires, 11 January 1986 (175);

Chilecito, La Rioja, 19 July 1981 (100).

Between 1985 and $1989,29,788$ birds were exported but during 1990 there were no exports of this species. Moreover, no export quota was authorized for 1993.

\section{Reddish-bellied Parakeet Pyrrhura frontalis}

The Reddish-bellied Parakeet is very common in the province of Misiones and common or fairly common in eastern Formosa and eastern Chaco. In Corrientes it is uncommon or occasional (pers. obs., and J. Contreras in litt.). The species has also been recorded from northern Santa Fe (Martínez Achenbach 1957), where there are no recent records. Saibene and Narosky (1983) and Klimaitis and Moschione (1987) reported it from north-eastern Buenos Aires, where probable escapes from the Zoological Garden may have established a wild population. It is possible to see small flocks crossing from the zoo to the adjacent Botanical Garden.

The sites at which we have recorded significant numbers of birds are:

Parque Nacional Iguazú, Misiones, June 1975 (80-100);

Pepirí Miní, Misiones, 25 July 1982 (80-100); 
Piñal Seco, Misiones, 1o December 1984 (50-60);

Riacho Monte Lindo, Formosa, 15 June 1989 (12-15);

Riacho He He, Formosa, 10 November 1986 (10-15).

From 1985 to $1990,29,678$ specimens were exported; this may have had a negative impact on the status of the species, but no export quota was authorized for 1993 .

\section{Green-cheeked Parakeet Pyrrhura molinae}

The Green-cheeked Parakeet is very common in Salta and Jujuy, and occasional in Tucumán. The report from Catamarca (Nores and Yzurieta 1981), based on a specimen collected in Valle de Santa María, is probably erroneous. Most likely the record corresponds to Santa María, Salta.

The sites at which we have recorded large numbers of birds are:

Parque Nacional El Rey, Salta, 25 September 1976 (80-100);

Agua Negra, Serranía de Calilegua, Jujuy, 15 March 1979 (70-80);

Campo Largo, Salta, 30 October 1982 (25-30);

Abra Colorada, Serranía de Calilegua, Jujuy, 10 October 1984 (20-30);

Cedro Solo, Río Santa María, Salta, 13 June 1987 (20-30);

Ocloyas, Jujuy, 16 October 1980 (15-20);

Acambuco, Salta, 1 November 1982 (15-20).

The Green-cheeked Parakeet is not widely traded. Only 1,345 birds were exported between 1985 and 1990, and no export quota was authorized for 1993 .

\section{Austral Conure Enicognathus ferrugineus}

The Austral Conure is fairly common to common throughout its range. It is found from Neuquén to Tierra del Fuego in the Andean forest zone.

The sites at which we have recorded significant numbers are:

Lago Huechulafquen, Neuquén, 23 March 1981 (150-200: S. Salvador verbally);

Parque Nacional Los Glaciares, January 1977 (20-30);

Puerto Blest, Río Negro, December 1979 (10-12);

Lago Huechulafquen, Neuquén, 22 January 1982 (8-10).

The Austral Conure is the most protected parrot in Argentina because there are several large national parks within its range.

It is not widely traded. Only 60 specimens were exported between 1985 and 1989 , and none in 1990.

\section{Monk Parakeet Myiopsitta monachus}

The Monk Parakeet is the commonest and most widely distributed parrot in Argentina. It ranges from Jujuy, Salta, Formosa and Misiones to northern Chubut. In some areas in the centre of the country it reaches substantial numbers (hundreds) while in the north and the south local populations do not exceed 50 or 100 individuals. 
Ridgely (1981) mentioned than in the Argentine pampas the Monk Parakeet has declined very noticeably since the 1960s. However, this seems mistaken as the species does not naturally inhabit the pampas. Just recently it has colonized some pampean areas, mainly in Eucalyptus plantations.

The sites at which we have recorded large numbers are:

Desembocadura del Río Segundo, Córdoba, 26 November 1975 (60o);

Río Primero, Córdoba, 16 July 1976 (500);

El Tío, Córdoba, 6 July 1976 (300-40o);

Villa Candelaria, Córdoba, 16 September 1975 (200-300);

Villa Dolores, Córdoba, 12 July 1979 (150-200);

Ingeniero Malmén, Córdoba, 16 April 1975 (100-150);

Parque Nacional El Palmar, Entre Ríos, 18 January 1984 (100-150);

Villa del Totoral, Córdoba, 27 July 1975 (80-100);

Laguna de Pocho, Córdoba, 14 July 1979 (80-100);

Villa Angela, Chaco, 15 December 1982 (80-100: S. Salvador verbally);

Sierra de Ambargasta, Santiago del Estero, 2 October 1980 (6o-80);

Bañado de Figueroa, Santiago del Estero, 6 May 1981 (40-50);

Aguas Chiquitas, Tucumán, September 1986 (40-50);

Bañado La Estrella (Posta km 45), Formosa, 20 July 1987 (40-50);

Bajos Submeridionales (10o km-tract), Santa Fe, 14 June 1984 (30-40);

Salar de Pipanaco, Catamarca, 2 November 1985 (30-40);

Hito Uno, Salta, 15 June $1987(30-40)$.

From 1985 to $1989,82,442$ parrots were exported but none was in 1990 . The export quota for 1993 was 24,000 , which is a high number.

\section{Grey-hooded Parakeet Bolborhynchus aymara}

The Grey-hooded Parakeet is fairly common. It ranges along the Andean zone from Jujuy to Mendoza and in the Sierras Pampeanas of Tucumán, Catamarca, La Rioja, Córdoba and San Luis.

The sites at which we have recorded significant numbers are:

Andean zone of Jujuy, January 1978 (40-50);

$100 \mathrm{~km}$ tract between La Toma and Santa Rosa (Ruta Nacional 48), San

Luis, 27 June $1981(40-50)$;

Intihuasi, San Luis, 25 June 1981 (30-35);

Río Yatán, Córdoba, 27 November 1974 (25-30);

Pampa de Achala, Córdoba, 13 January 1978 (20-30);

El Infiernillo, Tucumán, 21 June 1985 (20-25).

The Grey-hooded Parakeet is little traded internationally. Between 1985 and $1989,6,317$ birds were exported, and only 60 in 1990. No export quota was authorized for 1993 .

\section{Mountain Parakeet Bolborhynchus aurifrons}

The Mountain Parakeet is uncommon to fairly common and occurs from Jujuy to Mendoza in the Andean area, and in the Sierras Pampeanas of Tucuman, Catamarca, La Rioja and San Juan. Its presence in Córdoba (Burmeister 1861, 
Nores et al. 1983) and San Luis (Olrog 1959) needs to be confirmed. We have found it most frequently in the altiplano of Jujuy and in the Sierra de Famatina, La Rioja (up to 10 individuals).

The species is not traded internationally (only 250 birds between 1985 and 1990), and no export quota was authorized for 1993.

\section{Blue-winged Parrotlet Forpus xanthopterygius}

The Blue-winged Parrotlet is fairly common to uncommon, and occurs in Misiones, north-eastern Corrientes, eastern Formosa and eastern Chaco.

The maximum numbers we have recorded are as follows:

North-eastern Corrientes, June 1975 (20-30);

Parque Nacional Iguazú, Misiones, January 1978 (20-30: S. Salvador verbally);

Parque Nacional Iguazú, Misiones, June 1975 (15-20);

Tatané, Formosa, 13 July 1986 (8-10);

Itá Ibaté, Corrientes, 6 October 1979 (5-6: S. Salvador verbally).

The Blue-winged Parrotlet is very little traded internationally. Between 1985 and 1989, 1,426 parrots were exported, with none in 1990. No export quota was authorized for 1993 .

\section{Canary-winged Parakeet Brotogeris versicolurus}

The Canary-winged Parakeet is rare to uncommon in Argentina. It occurs in Salta, Formosa, Chaco and Misiones. The birds recorded in Buenos Aires City (Pérez 1990) are very probably escapes. We know of only five recent records:

Laishi department, Formosa, 7 July 1992 (7) (Contreras 1993);

Laishi department, Formosa, 7 September 1993 (2) (Contreras 1993);

Laishi department, Formosa, I December 1993 (2) (Contreras 1993);

Parque Nacional Iguazú, Misiones, 7 July 1985 (2: S. Salvador verbally);

Reserva El Bagual, Formosa (number not given: G. Sartori and P. Cichero verbally 1987).

We have never observed this species in Argentina. The previous records (from 1951) consisted of two specimens captured on Río Teuco, Formosa, 24 September, and two in Ingeniero G. N. Juárez, Formosa, 28 October (deposited at IML). Although Holmberg (1898) stated that this species was very common, the data provided by Azara (1805) showed just the contrary.

Despite its scarcity, from 1985 to 1990 no fewer than 46,522 birds were exported. It is clear that these birds were not from Argentina but from neighbouring countries where the species is more numerous and its trade is banned. No export quota was authorized for 1993.

\section{Red-capped Parrot Pionopsitta pileata}

The Red-capped Parrot is fairly common to uncommon in the province of Misiones. In north-eastern Corrientes, where it was also reported, there appear to be no recent records.

The maximum numbers we have recorded are as follows: 
Parque Nacional Iguazú, Misiones, June 1975 (15-20);

Pepirí Miní, Misiones, 25 July 1982 (15-20);

Piñal Seco, 1o December 1984 (10-12).

The Pileated Parrot is not exported from Argentina and it is not traded domestically. Because there was no prior estimate of population size, it is not possible to know if the species is in decline, as it is in Brazil (Sick and Teixeira 1979).

\section{Scaly-headed Parrot Pionus maximiliani}

The Scaly-headed Parrot is widely distributed in northern Argentina, but its abundance depends on the area. In the north-west it is common, being more abundant in southern Salta, Tucumán and adjacent areas of Catamarca. In southern and central Misiones, north-eastern Corrientes, the eastern parts of Formosa and Chaco and north-eastern Santa Fe it is fairly common. In northern Misiones it is generally uncommon, and in Entre Ríos it is occasional.

The sites at which we have recorded large numbers are:

Aguas Chiquitas, Tucumán, September 1976 (400-500);

Parque Nacional El Rey, Salta, 25 September 1976 (100-150);

Dique Sumampa, Catamarca, 26 November 1981 (40-50);

Los Narváez, Catamarca, 29 January 1983 (40-50);

Campo Largo, Salta, 30 October $1982(30-40)$;

Agua Negra, Serranía de Calilegua, Jujuy, 15 March 1979 (30-40).

From 1985 to $1990,60,060$ birds were exported. This probably represents a threat to the species. The export quota for 1993 was 4,000 , which is still a high number.

\section{Alder Amazon Amazona tucumana}

The Alder Amazon is uncommon in most of its range, although locally it may be found in large numbers. The species ranges in the mountains of Salta, Jujuy, Tucumán and Catamarca. Records from Chaco and Misiones (Zotta 1937) are very probably erroneous (see also Ridgely 1981). Large inaccessible areas of suitable habitat still persist in northern Salta so that the lack of recent records in that province does not necessarily indicate that the species has become extinct there.

The records we have are as follows:

Parque Nacional El Rey, Salta, 25 September 1976 (1,500-2,000);

El Clavillo, Catamarca-Tucumán border, 18 January 1983 (150-200);

San Javier, Tucumán, 21 June 1985 (50-60);

Abra Colorada, Serranía de Calilegua, Jujuy, 10 October 1984 (40-50);

Raco, Tucumán, 30 September 1979 (30-40);

Río Jordán, Serranía de Calilegua, Jujuy, 7 October 1984 (25-30);

Ocloyas, Jujuy, 16 October 1980 (4).

Despite its relative scarcity, from 1985 to 198918,641 birds were exported. This was evidently a serious threat to the species, but during 1990 no specimens were exported, and no export quota was authorized for 1993. 


\section{Red-spectacled Amazon Amazona pretrei}

The only recent records of the Red-spectacled Amazon in Argentina are a bird observed at Arroyo Urugua-i, Misiones, in February 1980 (Chebez et al. 1981); two birds in flight over Ruta Nacional 12, 2 km north of Garuhape, in December 1982 by F. Moschione and L. Pastorino; and an unspecified number in flight across the Río Paraná $2 \mathrm{~km}$ from Candelaria in July 1987 by F. Moschione and J. Sancristóbal (Collar et al. 1992). The previous records are those of two specimens collected in Santa Ana, Misiones, on October 1909 and September 1917 (MACN), and two specimens without data deposited at the Anibal Campos Museum, Posadas, Misiones (Chebez 1994).

The Red-spectacled Amazon was most likely never common in Argentina, since Araucaria forest has never been extensive there - a situation that has deteriorated further due to the almost complete destruction of these forests.

\section{Blue-fronted Amazon Amazona aestiva}

The Blue-fronted Amazon is still widely distributed in the northern part of the country, although its numbers have markedly declined in many areas, primarily in the Chaco region. It ranges from Jujuy, Salta, Formosa and Misiones to Cordoba, Santa Fe and Corrientes. It is still common in the basal forest of Salta and Jujuy, and fairly common to uncommon in the remaining area.

In Senda Hachada, Salta, in a tract of $5 \mathrm{~km}$, at sunset, 900 parrots crossed from the Chaco woodland to the forest on 23 June 1987 and 1,300 on 25 August 1987. A similar number was counted by Mosa et al. (1992) in Las Juntas, Salta.

On 13 June 1987, we counted 300 birds flying over a tract of about $2 \mathrm{~km}$ in Cedro Solo, Río Santa María, Salta.

Other sites at which we have recorded relatively large numbers are:

Pozo del Tigre, Formosa, I June 1989 (60-70);

Parque Nacional El Rey, Salta, 25 September 1976 (40-50);

Pozo del Mulato, Salta, 23 June 1987 (40-50);

Caimancito, Jujuy, 24 September 1987 (40-50);

Río Urueña, Tucumán, 21 October $1981(30-40)$;

La Ramadita, Tucumán, 21 June 1985 (30-40);

Batea, Salta, 10 June 1987 (25-30);

Dique Sumampa, Catamarca, 23 July 1982 (20-25);

Villa Guillermina, Santa Fe, 14 June 1982 (20-25);

Villa Ana, Santa Fe, 28 March 1975 (15-20).

At no location in the remainder of its distribution area did we record more than ten individuals.

Although current numbers are not particularly large, between 1985 and 1990 no fewer than 244,774 birds were exported, which represents a serious threat to the species. However, no export quota was authorized for 1993.

\section{Scaly-naped Amazon Amazona mercenaria}

The only record of the Scaly-naped Amazon from Argentina is that of a specimen captured by Hyeronymus in Orán, Salta, in 1882. It is deposited at the 
Museum of Zoology, Universidad Nacional de Córdoba, where it was located by the authors and described in Olrog (1979).

\section{Vinaceous Amazon Amazona vinacea}

Today, the Vinaceous Amazon is uncommon in the province of Misiones, although it used to be abundant in former times, as shown by comments in White (1882): "Both in Concepción and in San Javier the parrots are found in incredible numbers feeding in the orange-groves which cover and enclose the extensive Jesuit ruins in those parts of Misiones". A record from north-eastern Corrientes (Canevari et al. 1991) needs to be confirmed.

Until 1959 the species inhabited the Parque Nacional Iguazú, where it was observed by Eckelberry (1965), in Tobunas where W. Partridge collected 14 specimens (Navas and Bó 1988, LACM: 10 specimens), and on Arroyo Urugua-i (Navas and Bó 1988, LACM: 5 specimens).

The species's current range seems to be restricted to four small areas: (1) Campo Viera, where E. Maletti captured a specimen in July 1984 (located in the Museo de Ciencias Naturales de Oberá by J. C. Chebez) and where there were captive birds (pers. obs.) and wild birds (Proyecto Nauta in litt.); (2) Cruce Caballero, where wild and captive birds were observed (Proyecto Nauta in litt.);

(3) San Pedro, where 18 birds were observed (A. Giraudo verbally 1993); and

(4) San Antonio (Collar et al. 1992).

The species is not traded internationally.

\section{Purple-bellied Parrot Triclaria malachitacea}

The presence of the Purple-bellied Parrot in Argentina is based upon two recent records from Misiones: Parque Nacional Iguazú (Rumboll 1990) and on Arroyo Urugua-i (Canevari et al. 1991).

\section{Acknowledgements}

We wish to thank S. Salvador for participating and collaborating in part of the fieldwork for this report, and for the data he provided; and M. Christie for providing the LACM list of specimens from Argentina. D. Bruning made useful corrections to the manuscript. We are also grateful to J. Contreras, G. Nilsson, J. C. Chebez, L. Salvador, and Proyecto Nauta for providing data. Fieldwork was supported mainly by the ICBP (Pan American Section) and CONICOR.

Appendix. Gazetteer.

Only the localities that are not mentioned in Paynter (1985) are included herein.

Abra Colorada

Agua Negra

Aguas Chiquitas

Angosto del Pescado

Arroyo Tigre

Bajos Submeridionales $23^{\circ} 35^{\prime} \mathrm{S} 65^{\circ} \mathrm{oo}{ }^{\prime} \mathrm{W}$

$23^{\circ} 44^{\prime} \mathrm{S} 64^{\circ} 56^{\prime} \mathrm{W}$

$26^{\circ} 37^{\prime} \mathrm{S} 65^{\circ} 11^{\prime} \mathrm{W}$

$22^{\circ} 45^{\prime} \mathrm{S} 64^{\circ} 32^{\prime} \mathrm{W}$

$27^{\circ} 07^{\prime} \mathrm{S} 55^{\circ} 10^{\prime} \mathrm{W}$

$28^{\circ} 30^{\prime} \mathrm{S} 60^{\circ} \mathrm{oo}^{\prime} \mathrm{W}$ 


\begin{tabular}{|c|c|}
\hline Bañado La Estrella & $24^{\circ} 23^{\prime} \mathrm{S} 60^{\circ} 20^{\prime} \mathrm{W}$ \\
\hline Batea & $23^{\circ} 22^{\prime} \mathrm{S} 63^{\circ} 49^{\prime} \mathrm{W}$ \\
\hline Campo de Pucará & $27^{\circ} 4 \mathrm{O}^{\prime} \mathrm{S} 66^{\circ} \mathrm{O} 5^{\prime} \mathrm{W}$ \\
\hline Campo Viera & $27^{\circ} 23^{\prime} \mathrm{S} 55^{\circ} \mathrm{O} 2^{\prime} \mathrm{W}$ \\
\hline Cedro Solo & $23^{\circ} \times 5^{\prime} \mathrm{S} 64^{\circ} 25^{\prime} \mathrm{W}$ \\
\hline Cruce Caballero & $26^{\circ} 35^{\prime} \mathrm{S} 53^{\circ} 59^{\prime} \mathrm{W}$ \\
\hline Hito Uno & $22^{\circ} \mathrm{OO}^{\prime} \mathrm{S} 62^{\circ} 49^{\prime} \mathrm{W}$ \\
\hline Ingeniero Malmén & $34^{\circ} 47^{\prime} \mathrm{S} 64^{\circ} 48^{\prime} \mathrm{W}$ \\
\hline Lago Huechulafquen & $39^{\circ} 47^{\prime} \mathrm{S} 71^{\circ} 15^{\prime} \mathrm{W}$ \\
\hline La Lobería & $41^{\circ} 09^{\prime} \mathrm{S} 63^{\circ} 10^{\prime} \mathrm{W}$ \\
\hline La Ramadita & $27^{\circ} 06^{\prime} \mathrm{S} 65^{\circ} 37^{\prime} \mathrm{W}$ \\
\hline Las Juntas & $23^{\circ} 07^{\prime} \mathrm{S} 64^{\circ} 33^{\prime} \mathrm{W}$ \\
\hline Las Lomas & $28^{\circ} 29^{\prime} \mathrm{S} 58^{\circ} 59^{\prime} \mathrm{W}$ \\
\hline Los Cedros & $24^{\circ} 29^{\prime} \mathrm{S} 65^{\circ} 17^{\prime} \mathrm{W}$ \\
\hline Los Narváez & $27^{\circ} 40^{\prime} \mathrm{S} 65^{\circ} 56^{\prime} \mathrm{W}$ \\
\hline Ocloyas & $23^{\circ} 55^{\prime} \mathrm{S} 65^{\circ} 12^{\prime} \mathrm{W}$ \\
\hline Pampa de Achala & $31^{\circ} 35^{\prime} \mathrm{S} 64^{\circ} 50^{\prime} \mathrm{W}$ \\
\hline Parque Nacional Los Glaciares & $50^{\circ} 20^{\prime} S 72^{\circ} 40^{\prime} \mathrm{W}$ \\
\hline Piñal Seco & $26^{\circ} 50^{\prime} \mathrm{S} 53^{\circ} 42^{\prime} \mathrm{W}$ \\
\hline Playa Ancha & $22^{\circ} 07^{\prime} \mathrm{S} 63^{\circ} 46^{\prime} \mathrm{W}$ \\
\hline Pozo del Mulato & $23^{\circ} 22^{\prime} \mathrm{S} 64^{\circ} 12^{\prime} \mathrm{W}$ \\
\hline Pozo del Tigre & $24^{\circ} 54^{\prime} \mathrm{S} 60^{\circ} 19^{\prime} \mathrm{W}$ \\
\hline Quebrada de Sébila & $28^{\circ} 45^{\prime} \mathrm{S} 66^{\circ} 27^{\prime} \mathrm{W}$ \\
\hline Reserva de Copo & $26^{\circ} 10^{\prime} \mathrm{S} 61^{\circ} 50^{\prime} \mathrm{W}$ \\
\hline Reserva El Bagual & $26^{\circ} 11^{\prime} S 58^{\circ} 49^{\prime} \mathrm{W}$ \\
\hline Riacho $\mathrm{He} \mathrm{He}$ & $25^{\circ} 37^{\prime} \mathrm{S} 57^{\circ} 51^{\prime} \mathrm{W}$ \\
\hline Riacho Monte Lindo & $25^{\circ} 49^{\prime} \mathrm{S} 5^{\circ} 8^{\circ} 1^{\prime} \mathrm{W}$ \\
\hline Riacho Pilagá & $26^{\circ} \mathrm{Oo}^{\prime} \mathrm{S} 58^{\circ} 10^{\prime} \mathrm{W}$ \\
\hline Riacho San Hilario & $26^{\circ} 16^{\prime} \mathrm{S} 58^{\circ} 17^{\prime} \mathrm{W}$ \\
\hline Río Jordán & $23^{\circ} 40^{\prime} \mathrm{S} 64^{\circ} 57^{\prime} \mathrm{W}$ \\
\hline San Pablo Norte & $32^{\circ} 39^{\prime} \mathrm{S} 65^{\circ} 18^{\prime} \mathrm{W}$ \\
\hline Senda Hachada & $23^{\circ} \mathrm{o3}^{\prime} \mathrm{S} 63^{\circ} 5^{\prime} \mathrm{W}$ \\
\hline Sierra Colorada & $25^{\circ} 40^{\prime} \mathrm{S} 64^{\circ} 30^{\prime} \mathrm{W}$ \\
\hline Tatané & $26^{\circ} 24^{\prime} \mathrm{S} 5^{\circ} 21^{\prime} \mathrm{W}$ \\
\hline Vilismán & $28^{\circ} 29^{\prime} \mathrm{S} 65^{\circ} 27^{\prime} \mathrm{W}$ \\
\hline Villa de Soto & $30^{\circ} 51^{\prime} \mathrm{S} 64^{\circ} 59^{\prime} \mathrm{W}$ \\
\hline Villa Guillermina & $28^{\circ} 14^{\prime} \mathrm{S} 59^{\circ} 28^{\prime} \mathrm{W}$ \\
\hline Winifreda & $36^{\circ} 15^{\prime} \mathrm{S} 64^{\circ} 14^{\prime} \mathrm{W}$ \\
\hline
\end{tabular}

\section{References}

Anon. (1993) Export quotas for psittacines (Argentina). Traffic Bull. 13: 91.

Azara, F. de (1805) Apuntamientos para la historia natural de los páxaros del Paraguay y Río de la Plata. Madrid: Imprenta de la Viuda de Ibarra.

Bucher, E. H. and Rinaldi, S. (1986) Distribución y situación actual del loro barranquero (Cyanoliseus patagonus) en la Argentina. Vida Silv. Neotrop. 1: 55-61.

Burmeister, H. (1861) Reise durch die La Plata-Staaten, mit besonderer Rücksicht auf die physische Beschaffenheit und der culturzustand der Argentinischen Republik. Halle: H. W. Schmidt. 
Canevari, M., Canevari, P., Carrizo, G. R., Harris, G., Rodríguez Mata, J. and Straneck, R. (1991) Nueva guía de las aves argentinas. Buenos Aires: Fundación Acindar.

Casares, J. (1944) Aves de Estanzuela, San Luis. Hornero 8: 379-463.

Chebez, J. C. (1990) Los manuscriptos de William Henry Partridge. Nuestras Aves 22: 20-24.

Chebez, J. C. (1994) Los que se van: especies argentinas en peligro. Buenos Aires: Ed. Albatros.

Chebez, J. C., Tubaro, P., Gallegos-Luque, D., García, G. and Viceconte, F. (1981) Sobre la necesidad de proteger el Arroyo Urugua-i en Misiones. Iguazú 1: 1-98.

Collar, N. J., Gonzaga, L. P., Krabbe, N., Madroño Nieto, A., Naranjo, L. G., Parker, T. A. and Wege, D. C. (1992) Threatened birds of the Americas: the ICBP Red Data Book. Cambridge, U.K.: International Council for Bird Preservation.

Contreras, J. R. (1981) Lista preliminar de la avifauna correntina. 1. No Passeriformes. Hist. Nat. 2: 21-28.

Contreras, J. R. (1993) Acerca de algunas especies de aves del extremo sudeste de la Provincia de Formosa. Nótulas Faunísticas 47: 1-8.

Contreras, J. R., Garello, A. A. and Krauczuc, E. R. (1994) Consideraciones acerca de diez especies interesantes de la Provincia de Misiones. Nótulas Faunísticas 52: 1-8.

Eckelberry, D. R. (1965) A note on the parrots of northeastern Argentina. Wilson Bull. 77: 111.

Edwards, S. R. and Villalba Macías, J. (1992) Wild bird trade: perceptions and management in Argentina. Pp.61-75 in J. B. Thomsen, S. R. Edwards and T. A. Mulliken, eds. Perceptions, conservation and management of wild birds in trade. Cambridge, U.K.: Traffic International.

Fontana, L. J. (1881) El gran chaco. Buenos Aires.

Forshaw, J. M. (1978) Parrots of the world. Second edition. Melbourne: Lansdowne Editions.

Frenzel, J. (1891) Uebersicht über die in der Provinz Córdoba (Argentinien) vorkommenden Vögel. J. Orn. 39: 113-126.

Holmberg, E. L. (1898) Aves. In: Fauna Argentina. Segundo Censo de la República Argentina (1895) 1: 494-574.

Hoy, G. (1969) Addendas a la avifauna salteña. Hornero 11: 53-56.

Ingels, J., Parkes K. C. and Farrand, J. (1981) The status of the macaw generally but incorrectly called Ara caninde (Wagler). Gerfaut 71: 283-294.

Jordan, O. C. and C. A. Munn (1993) First observations of the Blue-throated Macaw in Bolivia. Wilson Bull. 105: 694-695.

Jorgenson, A. and Thomsen, J. B. (1987) Neotropical parrots imported by the United States, 1981 to 1985 . Traffic U.S.A. 7: 3-8.

Klimaitis, J. F. and Moschione, F. N. (1987) Aves de la reserva integral de selva marginal de Punta Lara y sus alrededores. Buenos Aires: Dir. Serv. Gen. Min. Econ. Pcia.

Lynch Arribálzaga, E. (1920) Las aves del Chaco. Hornero 2: 85-98.

Martínez Achenbach, G. (1957) Lista de las aves de la provincia de Santa Fe. Anal. Mus. Prov. Cienc. Nat. Florentino Ameghino 1: 1-61.

Moschione, F. N. (1992) Comentarios sobre la presencia en la rivera platense del Loro Barranquero Cyanoliseus patagonus. Garganchillo 12: 12-13.

Navas, J. R. and Bó, N. A. (1988) Aves nuevas o poco conocidas de Misiones, Argentina. II. Com. Zool. Mus. Hist. Nat. Montevideo 12: 1-9.

Nilsson, G. (1985) Importation of birds into the United States 1980-1984. Washington D.C.: Animal Welfare Institute.

Nores, M. and Yzurieta, D. (1981) Nuevas localidades para aves argentinas. Hist. Nat. 2: $33-42$.

Nores, M., Yzurieta, D. and Miatello, R. (1983) Lista y distribución de las aves de Córdoba, Argentina. Bol. Acad. Nac. Cienc. Córdoba 56: 1-114. 
Olrog, C. C. (1958) Notas ornitológicas sobre la colección del Instituto Miguel Lillo, Tucumán. 3. Acta Zool. Lilloana 15: 5-19.

Olrog, C. C. (1959) Las aves argentinas, una guía de campo. Tucumán: Instituto Miguel Lillo.

Olrog, C. C. (1979) Nueva lista de la avifauna argentina. Op. Lilloana 27.

d'Orbigny, A. (1835-1847) Voyage dans l'Amérique Méridionale. Paris.

Paynter, R. A. (1985) Ornithological gazetteer of Argentina. Cambridge, Mass.: Museum of Comparative Zoology.

Pérez, J. H. (1990) Catita chirirí (Brotogeris versicolurus) en Capital Federal. Nuestras Aves 21: 27-28.

Peters, J. L. (1937) Check-list of birds of the world, 3. Cambridge, Mass.: Museum of Comparative Zoology.

Ridgely, R. S. (1981) The current distribution and status of mainland neotropical parrots. Pp.233-384 in R.F. Pasquier, ed. Conservation of New World parrots. Washington D.C.: Smithsonian Institution Press for the International Council for Bird Preservation (Techn. Publ. 1).

Rumboll, M. A. E. (1990) Tres nuevas aves para La Argentina. Nuestras Aves 22: 28.

Saibene, C. and Narosky T. (1983) Presencia del chiripipé común, Pyrrhura frontalis (Vieillot) en la provincia de Buenos Aires. Nuestras Aves: 2: 4.

Salvadori, T. (1891) Psittaci. Catalogue of the birds in the British Museum, 20. London: Trustees of the British Museum.

Sánchez-Labrador, J. (1767) Peces y aves del Paraguay natural ilustrado. Ed. M. N. Castex (1968). Buenos Aires: Comp. Gen. Fabril Ed.

Sick, H. and Teixeira, D. M. (1979) Notas sobre aves brasileiras raras ou ameaçadas de extinção. Publ. Avuls. Mus. Nac. 62.

Torrano, F. J. (1990) Aratinga leucophthalma en Concordia, Entre Ríos. Nuestras Aves 22: 30.

White, E. W. (1882) Notes on birds collected in the Argentine Republic. Proc. Zool. Soc. London: $591-629$.

Yamashita, C. and Valle, M. P. (1993) On the linkage between Anodorhynchus macaws and palm nuts, and the extinction of the Glaucous Macaw. Bull. Brit. Orn. Club 113: 53-60.

Zotta, A. R. (1944) Lista sistemática de las aves argentinas. Tirada del Mus. Arg. Cienc. Nat. Buenos Aires.

MANUEL NORES

Consejo Nacional de Investigaciones Cientificas y Técnicas, Centro de Zoología Aplicada, C. de C. 122, 500o Córdoba, Argentina

DARIO YZURIETA

Costa Canal 420, 5147 Argüello, Córdoba, Argentina 